\title{
Effect of pH and Calcium Concentration on Proteolysis in Mozzarella Cheese
}

\author{
E. P. Feeney*, T. P. Guinee, $†$ and P. F. Fox* \\ *Food Chemistry, Department of Food Science and Technology, \\ University College, Cork, Ireland and \\ †Dairy Products Research Centre, Teagasc, \\ Moorepark, Fermoy, Co. Cork, Ireland
}

Small peptides, amino acids, and especially products of amino acid catabolism, e.g., amines and thiols, contribute directly to cheese flavor (Fox et al., 1996; McSweeney and Sousa, 2000). Proteolysis is a major determinant of the intact casein content which has a large impact on the texture of the unheated Cheddar cheese (Creamer and Olson, 1982) and on the functionality of heated cheese (Guinee et al., 2000a).

Owing to its importance in cheese ripening, proteolysis and factors affecting it have been investigated extensively in different cheese varieties, especially Cheddar (O'Keeffe et al., 1975; Lane and Fox, 1997). $\alpha_{\mathrm{s} 1}$-Casein is the principal target of chymosin and most other commercial rennets in rennet-curd cheese varieties. The early hydrolysis of $\alpha_{\mathrm{s} 1}-\mathrm{CN}$ at the $\mathrm{Phe}_{23}-\mathrm{Phe}_{24}$ peptide bond by residual chymosin results in a marked weakening of para-casein matrix and decreases in fracture stress and firmness (Creamer and Olson, 1982; Fenelon et al., 2000). $\beta$-Casein generally undergoes markedly less breakdown than $\alpha_{\mathrm{s} 1} \mathrm{CN}$ during storage of most cheeses, including Cheddar, Gouda, and Mozzarella (Visser and de Groot-Mostert, 1977; Yun et al., 1993; Fox et al., 1996).

A recent survey (Guinee et al., 2000b) indicated marked intravarietal differences in the Ca-to-casein ratio and $\mathrm{pH}$ of retail Cheddar and Mozzarella, which undoubtedly reflect the application of different cheesemaking protocols at a commercial level for the manufacture of cheese with different heat-induced functionality. Functional attributes of cheese, such as flow and stretchability, are influenced by $\mathrm{pH}$ and $\mathrm{Ca}$ content (Kimura et al., 1992; Guinee et al., 2002).

Little information is available on the direct effects of $\mathrm{pH}$ and $\mathrm{Ca}$ content on proteolysis in cheese, including Mozzarella. However, studies indicate that proteolysis of $\mathrm{CN}$ in dilute systems depends on the reaction $\mathrm{pH}$ and the state of aggregation of the substrate, as affected by $\mathrm{pH}$ and Ca content (Mulvihill and Fox, 1977). Fox (1970) reported that the individual CNS in milk, especially $\alpha_{\mathrm{s} 1}-\mathrm{CN}$, become progressively more susceptible to rennet-induced proteolysis at $\mathrm{pH} 6.6$ as the level of micellar calcium phosphate is reduced. This effect was 
attributed to the increased accessibility of individual CNS to rennet, owing to the disruption of the micelles on removal of colloidal calcium phosphate. Similarly, reducing the level of calcium phosphate in Cheddar cheese curd (by a rapid decrease in $\mathrm{pH}$ ), while in contact with the whey containing the full amount of rennet, results in increased susceptibility of the $\mathrm{CN}$ to proteolysis and a higher degree of CN degradation in 1-d-old cheese (O'Keeffe et al., 1975).

Tam and Whitaker (1972) found that the extent of hydrolysis in dilute $(\sim 0.5 \%, \mathrm{wt} / \mathrm{vol})$ aqueous dispersions of whole $\mathrm{CN}$ and $\alpha_{\mathrm{s} 1^{-}}$or $\beta$-CN by chymosin generally decreased as the $\mathrm{pH}$ was increased from 3.5 to 6.0. Mulvihill and Fox (1977) reported that in the $\mathrm{pH}$ range 4.0 to 7.0 , the hydrolysis of $\alpha_{\mathrm{s} 1} \mathrm{CN}(2 \%$, wt/vol, aqueous dispersion) to $\alpha_{\mathrm{s} 1}-\mathrm{CN}$ (f24-199) by chymosin was optimal at $\mathrm{pH} 5.8$ and minimal at $\mathrm{pH} 4.6$, where the $\alpha_{\mathrm{s} 1^{-}}$ $\mathrm{CN}$ (f24-199) is aggregated. Moreover, the rate of degradation of $\alpha_{\mathrm{s} 1}-\mathrm{CN}$ (f24-199) and the profile of its products are influenced by reaction $\mathrm{pH}$, with the degradation of $\alpha_{\mathrm{s} 1}-\mathrm{CN}$ (f 24-199) to $\alpha_{\mathrm{s} 1}-\mathrm{CN}$ (f102-199) being optimal at pH 5.8 (Mulvihill and Fox, 1977). However, the influence of $\mathrm{pH}$ on the proteolytic activity and specificity of chymosin on $\alpha_{\mathrm{s} 1}-\mathrm{CN}$ (f24-199) is influenced by $\mathrm{NaCl}$ (Mulvihill and Fox, 1980). At a rennet level typical of that used in cheese manufacture (i.e., $~ 2.2 \mathrm{CU} / \mathrm{ml}$ ), hydrolysis of $\alpha_{\mathrm{s} 1}-\mathrm{CN}$ to $\alpha_{\mathrm{s} 1} \mathrm{CN}$ (f24-199) and further hydrolysis of $\alpha_{\mathrm{s} 1}-\mathrm{CN}$ (f24-199) is markedly inhibited at $5 \% \mathrm{NaCl}$ in the $\mathrm{pH}$ range 5.8 to 7.0 . In contrast, at $\mathrm{pH}$ 5.2 the addition of $\mathrm{NaCl}$ to $5 \%$, wt/vol, had little effect on the degree of chymosin-induced degradation of $\alpha_{\mathrm{s} 1^{-}}$ $\mathrm{CN}$ to $\alpha_{\mathrm{s} 1}-\mathrm{CN}$ (f24-199) but strongly inhibited further proteolysis of $\alpha_{\mathrm{s} 1}-\mathrm{CN}$ (f24-199). Owing to the $\mathrm{pH}$ dependence of the inhibitory effect of $\mathrm{NaCl}$, the degree of overall hydrolysis of $\alpha_{\mathrm{s} 1}-\mathrm{CN}$ in the presence of $5 \%$, wt/ vol, $\mathrm{NaCl}$ increased as the $\mathrm{pH}$ was reduced in the range 6.4 to 5.2 .

The objective of this study was to investigate the effect of $\mathrm{pH}$ and $\mathrm{Ca}$ content and their interaction on proteolysis in low-fat Mozzarella cheese.

\section{MATERIALS AND METHODS}

\section{Cheese Manufacture}

The manufacturing procedures for the experimental cheeses have been described in detail by Guinee et al. (2002). Milk was standardized to a casein:fat ratio of 0.95 , pasteurized $\left(72^{\circ} \mathrm{C}, 15 \mathrm{~s}\right)$, cooled to $36^{\circ} \mathrm{C}$, and divided into four $450-\mathrm{L}$ quantities per vat. The manufacturing procedures for the four cheeses differed with respect to: 1) method of acidification, i.e., a starter culture $(15 \mathrm{~g} / \mathrm{kg})$ consisting of Streptococcus thermophilus and Lactobacillus helveticus for the control (CL) cheese; direct acidification by the addition of lactic acid ( $5 \mathrm{~g} /$
$100 \mathrm{ml}$ ) to milk at $36^{\circ} \mathrm{C}$ (DA1 cheese); or direct acidification by the addition of lactic acid to the milk and glucono- $\delta$-lactone (GDL) as a powder mixed with the salt and added to the curd at a level of 1.6 or $3.6 \mathrm{~g} / 100$ g curd for the DA2 and DA3 cheeses, respectively. 2) $\mathrm{pH}$ of milk at rennet addition (setting), $\mathrm{pH}$ of the curd at whey drainage and at milling, i.e., 5.6, 5.6, and 5.6, respectively, for DA1; 6.55, 6.15, and 5.15 for CL and DA3; $6.5,6.15$, and 5.60 for DA2.

The CL cheese was manufactured using a dry-salting procedure as described by Guinee et al. (2000c). The manufacture of the DA cheeses was similar to that of the CL cheese except for the differences noted above. For all treatments, the salted curd was mellowed for $20 \mathrm{~min}$, kneaded, and heated to $58^{\circ} \mathrm{C}$ in hot water, and molded into rectangular $2.3 \mathrm{-kg}$ blocks. The blocks were cooled in dilute brine $\left(10 \mathrm{~g}\right.$ of NaCl$/ 100 \mathrm{~g}, 0.2 \mathrm{~g} \mathrm{CaCl}_{2} /$ $100 \mathrm{~g}, \mathrm{pH}$ 5.1) at $\sim-4^{\circ} \mathrm{C}$ to a core temperature of $<$ $45^{\circ} \mathrm{C}$ for $30 \mathrm{~min}$, vacuum-wrapped, and stored at $4^{\circ} \mathrm{C}$. Cheesemaking was performed in triplicate.

\section{Cheese Composition}

Grated cheese was analyzed in duplicate for fat, protein, moisture, $\mathrm{pH}$ and $\mathrm{Ca}$, as described by Guinee et al. $(2000 \mathrm{c})$.

\section{Proteolysis}

The level of cheese nitrogen soluble in water at $\mathrm{pH}$ 4.6 (pH4.6SN; Kuchroo and Fox, 1982) or in 5\% (wt/ wt) tungstophosphoric acid (PTAN; Guinee et al., 2000b) was measured.

Urea-polyacrylamide gel electrophoresis (ureaPAGE) was performed on whole cheese samples and the $\mathrm{pH}$ 4.6-soluble fraction of the cheeses using a protean IIxi vertical slab gel unit (Bio-Rad Laboratories, Ltd., Watford, UK) and a stacking gel system, as described by Lane and Fox (1997). The gels were stained directly with Coomassie brilliant blue G250, as described by Lane and Fox (1997).

The lyophilized pH4.6SN and the ethanol-soluble fraction thereof were analyzed by reverse-phase HPLC (RP-HPLC). The ethanol-soluble fraction was prepared as follows: Absolute ethanol was added to an aliquot of the $\mathrm{pH} 4.6$-soluble fraction to a final ethanol concentration of $700 \mathrm{ml} / \mathrm{L}$. The mixture was held for 30 min at $20^{\circ} \mathrm{C}$ and centrifuged at $3000 \times g$ for $30 \mathrm{~min}$. The supernatant was filtered through Whatman No. 1 filter paper, and the ethanol was removed from the filtrate by rotary evaporation (model no. RE100, Bibby Sterelin, Ltd., Stone, UK) at $30^{\circ} \mathrm{C}$ under vacuum; the residue was lyophilized. The lyophilized sample was dissolved in Solvent A $[1 \mathrm{ml} / \mathrm{L}$ of trifluoroacetic acid 
Table 1. Compositional analysis of low-moisture Mozzarella cheese made using starter culture (CL) or direct acidification (DA) with different $\mathrm{pH}$ values at setting, whey drainage, and plasticization. Values presented are the means of three replicates.

\begin{tabular}{lllcc}
\hline & & \multicolumn{3}{c}{ Cheese code } \\
\cline { 3 - 5 } Composition & CL & DA1 & DA2 & DA3 \\
\hline Moisture (\%, wt/wt) & $48.00^{\mathrm{b}}$ & $56.73^{\mathrm{a}}$ & $49.35^{\mathrm{b}}$ & $50.78^{\mathrm{b}}$ \\
Fat $(\%, \mathrm{wt} / \mathrm{wt})$ & $20.33^{\mathrm{a}}$ & $15.94^{\mathrm{b}}$ & $16.89^{\mathrm{b}}$ & $16.16^{\mathrm{b}}$ \\
Protein $(\%, \mathrm{wt} / \mathrm{wt})$ & $27.00^{\mathrm{a}}$ & $23.52^{\mathrm{b}}$ & $28.51^{\mathrm{a}}$ & $27.61^{\mathrm{a}}$ \\
MNFS $^{1}(\%, \mathrm{wt} / \mathrm{wt})$ & $60.25^{\mathrm{b}}$ & $67.43^{\mathrm{a}}$ & $59.38^{\mathrm{b}}$ & $60.57^{\mathrm{b}}$ \\
Ca $(\mathrm{mg} / \mathrm{g}$ protein) & $27.7^{\mathrm{a}}$ & $21.8^{\mathrm{b}}$ & $29.6^{\mathrm{a}}$ & $28.7^{\mathrm{a}}$ \\
pH at 1d & $5.42^{\mathrm{b}}$ & $5.96^{\mathrm{a}}$ & $5.93^{\mathrm{a}}$ & $5.58^{\mathrm{b}}$ \\
\hline
\end{tabular}

${ }^{a, b}$ Values within a row not sharing a common superscript differed significantly $(P<0.05)$.

${ }^{1}$ MNFS $=$ Moisture-in-nonfat substances

(TFA) in HPLC-grade water] and a sample $(40 \mu \mathrm{l})$ was injected onto a Nucleosil $\mathrm{C}_{8}$ reversed phase column $(250$ $\times 4.6 \mathrm{~mm}, 5 \mu \mathrm{m}$ ), equilibrated with solvent A on a Varian Prostar 230 HPLC unit, as described by Lane and Fox (1997). The sample was eluted at a flow rate of $0.75 \mathrm{ml}$ min $^{-1}$. The gradient was started with $100 \%$ solvent A for 5 min and continued with a linear gradient to $50 \%$ ( $\mathrm{vol} / \mathrm{vol})$ solvent B ( $1 \mathrm{ml} / \mathrm{L}$ of TFA in acetonitrile) for 55 $\mathrm{min}, 50 \% \mathrm{~B}(\mathrm{vol} / \mathrm{vol})$ for $6 \mathrm{~min}$, and a linear gradient to $60 \% \mathrm{~B}$ ( vol/vol) for $3 \mathrm{~min}$. The column was washed with $95 \% \mathrm{~B}(\mathrm{vol} / \mathrm{vol})$ for $5 \mathrm{~min}$, followed by equilibration with $100 \% \mathrm{~A}$ for $5 \mathrm{~min}$ before the next injection.

\section{Statistical Analysis}

A randomized complete block design, which incorporated the four treatments and three blocks (replicate trials), was used for analysis of the response variables related to the composition of the cheeses (Table 1). A split plot design was used to monitor the effects of treatment, storage time, and their interaction on $\mathrm{pH} 4.6 \mathrm{SN}$ and PTAN. Analysis of variance for the split plot design was carried out using a general linear model procedure (SAS, 1995). Statistically significant differences $(P<$
0.05) between different treatment levels were determined by Fisher's least significant difference.

The four cheeses from each of the three trials were analyzed by PAGE after different storage times; similarly, the $\mathrm{pH} 4.6$-soluble extracts and the $75 \%$ ethanol soluble extracts were lyophilized and examined by RPHPLC. The latter results are presented as observations and supportive data but were not statistically analyzed.

\section{RESULTS AND DISCUSSION}

\section{Cheese composition}

The compositions of the cheeses, which have been described previously (Guinee et al., 2002), are summarized in Table 1. Compared to the other cheeses, DA1 had a significantly higher moisture content and moisture in nonfat substances, and lower concentrations of $\mathrm{Ca}$ and protein. The fat content in CL was significantly higher than that of the other cheeses. The $\mathrm{pH}$ of the CL and DA3 cheeses at $1 \mathrm{~d}$ was significantly lower than that of the DA1 and DA2 cheeses.

Table 2. Mean squares (MS) and probabilities (P) for changes in proteolysis in low-moisture Mozzarella cheeses made using different procedures and with different $\mathrm{pH}$ and calcium levels. ${ }^{1}$.

\begin{tabular}{|c|c|c|c|c|c|c|}
\hline \multirow[b]{2}{*}{ Factors } & \multicolumn{3}{|c|}{$\begin{array}{c}\mathrm{pH} 4.6 \text {-soluble } \mathrm{N} \\
(\% \text { of total } \mathrm{N})\end{array}$} & \multicolumn{3}{|c|}{$\begin{array}{c}5 \% \text { (wt/wt) Phophotungstic } \\
\text { acid-soluble N } \\
\text { (\% of total N) }\end{array}$} \\
\hline & df & MS & $P$ & $\mathrm{df}$ & MS & $P$ \\
\hline \multicolumn{7}{|l|}{ Main plot } \\
\hline Make procedure & 3 & 19.4 & $<0.001$ & 3 & 0.53 & $<0.001$ \\
\hline Error & 6 & 0.59 & & 6 & 0.01 & \\
\hline \multicolumn{7}{|l|}{ Sub-plot } \\
\hline Time & 6 & 33.7 & $<0.001$ & 6 & 0.03 & $<0.001$ \\
\hline Interaction & 18 & 0.54 & $<0001$ & 18 & 003 & $<0001$ \\
\hline Error & 48 & 0.17 & & 48 & 0.02 & \\
\hline
\end{tabular}

${ }^{1}$ Differences in make procedure are given in text. 

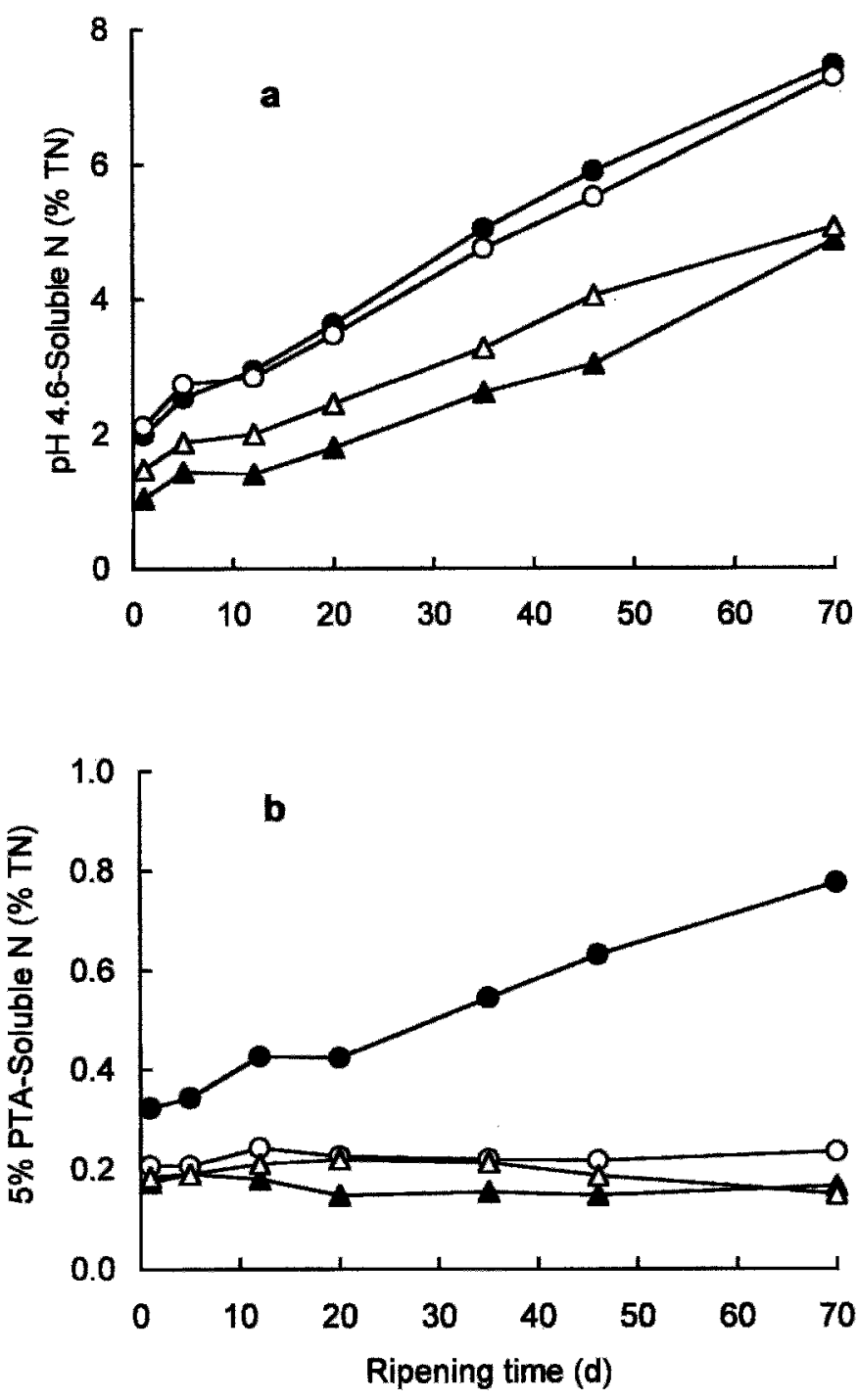

Figure 1. Age-related changes in the concentration of $\mathrm{pH} 4.6$ soluble $\mathrm{N}$ (a) and 5\% (wt/wt) phosphotungstic acid soluble N (b) in low-moisture Mozzarella cheeses made using conventional starter culture acidification $(\bullet)$ or direct acidification $(\bigcirc, \boldsymbol{\Delta}, \triangle)$. The cheesemaking procedure was altered to give cheeses of different $\mathrm{pH}$ and Ca content (mg/g protein): 5.42 and 27.7 (control; $) ; 5.96$ and 21.8 (DA1; O); 5.93 and 29.6 (DA2; $\mathbf{\Delta}$ ), and 5.58 and 28.7 (DA3; $\triangle$ ). Details of make procedures and composition are given in the text. Values presented are the means from three replicate trials.

\section{pH4.6SN and PTAN}

The concentration of $\mathrm{pH} 4.6 \mathrm{SN}$ as a percentage of total $\mathrm{N}$ increased significantly in all cheeses during maturation (Figure 1a), with the level in the CL cheese at 50 $\mathrm{d}(\sim 6 \%$ total $\mathrm{N})$ being typical of that reported previously by other Irish workers (Guinee et al., 1998; Walsh et al., 1998; Guinee et al., 2000c; Feeney et al., 2001) and somewhat higher than the mean level $(4.7 \%$ total $\mathrm{N})$ found in retail and wholesale samples of Mozzarella in
Ireland, UK, and Denmark (Guinee et al., 2000b). In contrast, the level of $\mathrm{pH} 4.6 \mathrm{SN}$ in the CL cheese was lower than typical values ( $~ 8$ to $10 \%$ total $\mathrm{N}$ at $50 \mathrm{~d}$ ) reported for Mozzarella in studies from the United States (Yun et al., 1993a, 1993b; Kindstedt et al., 1995; Renda et al., 1997). The comparatively low level of $\mathrm{pH} 4.6 \mathrm{SN}$ in the CL cheese compared with that in Mozzarella cheeses in the latter studies may be attributed to the higher $\mathrm{pH}$ of the CL curd during plasticization and subsequent ripening (e.g., 5.45 vs. typical values of 5.1 to 5.2 at $1 \mathrm{~d}$; Guinee et al., 2002), and the higher temperature used for plasticization of $\mathrm{CL}\left(58^{\circ} \mathrm{C}\right.$ vs. $55^{\circ} \mathrm{C}$ in some studies in the United States). A higher $\mathrm{pH}$ would result in greater inactivation of rennet during heating and plasticization of the curd (Thunell et al., 1979) and would be less favorable for the proteolysis in the curd by residual rennet during storage (Tam and Whitaker, 1972; Mulvihill and Fox, 1980).

The mean concentration of $\mathrm{pH} 4.6 \mathrm{SN}$ was significantly affected by the interaction of make procedure and storage time (Table 2). At most analysis times, the mean level of pH4.6SN in the CL and DA1 cheeses was similar and significantly higher than that in the DA2 and DA3 cheeses. The higher level of proteolysis in the DA1 cheese, compared with the DA2 and DA3 cheeses, may be attributed to a number of factors: (1) the higher content of moisture-in-nonfat substance, which favors proteolysis (Creamer, 1971); (2) increased susceptibility of casein to proteolysis by residual rennet due to the lower calcium content while the curd is in contact with the whey and during subsequent storage (Fox, 1970; O'Keeffe et al., 1975); and (3) an expected greater retention of rennet in the cheese due to the lower $\mathrm{pH}$ at setting and at whey drainage (Creamer et al., 1985). The higher level of proteolysis in the CL cheese compared to DA2, despite the similar value for $\mathrm{pH}$ at setting and at draining, may be related to its lower final $\mathrm{pH}$, which should increase the stability of retained rennet (Thunell et al., 1979) and proteolysis by rennet (Tam and Whitaker, 1972; Mulvihill and Fox, 1977, 1980). The greater proteolysis in the CL cheese compared to DA3 may be due to its slightly lower $\mathrm{pH}$ and to the use of a starter culture, which makes a relatively small (compared to chymosin) but significant contribution to the formation of pH4.6SN in Cheddar (O'Keeffe et al., 1978) and Gouda (Visser, 1977) cheeses.

The level of secondary proteolysis in the CL cheese was significantly higher than in the DA cheeses, as reflected by its significantly higher level of PTAN (Figure 1b), which is comprised of amino acids and small peptides with a molecular mass $<1.5 \mathrm{kDa}$ (Jarrett et al., 1982). The higher concentrations of PTAN in the CL cheese is attributed to the activity of starter proteinases 

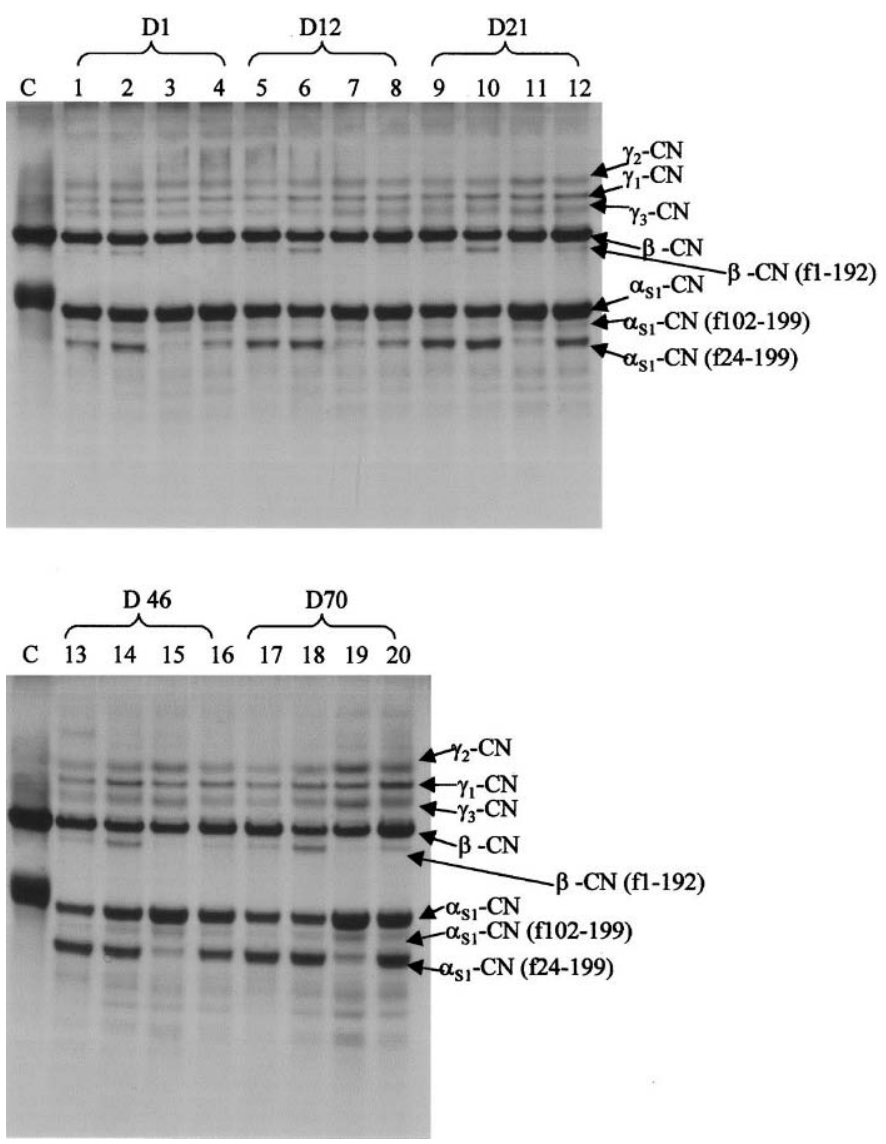

Figure 2. Urea-PAGE of sodium caseinate (C) and Mozzarella cheese made using conventional starter culture acidification ( $\mathrm{pH} 5.42$, Ca $27.7 \mathrm{mg} / \mathrm{g}$ of protein) (control; lanes, 1, 5, 9, 13 and 17) or direct acidification to give cheeses with $\mathrm{pH}$ and Ca levels ( $\mathrm{mg} / \mathrm{g}$ protein) of 5.96 and 21.8 (DA1; lanes 2, 6, 10, 14, and 18); 5.93 and 29.6 (DA2; lanes, $3,7,11,15$, and 19), or 5.58 and 28.7 (DA3; 4, 8, 12, 16, and 20 ) after ripening for $1,12,21,46$, and $70 \mathrm{~d}$ at $4^{\circ} \mathrm{C}$. Details of make procedures and composition are given in the text.

and peptidases (Visser, 1977; O'Keeffe et al., 1978), which were not present in the DA cheeses.

\section{Urea-PAGE}

Cheese. Urea-PAGE gel electrophoretograms of the different cheeses are shown in Figure 2. The overall degradation pattern of the control cheese was similar to that reported elsewhere for low-moisture Mozzarella (Creamer, 1976; Kindstedt and Guo, 1997). In general, the trend observed with urea-PAGE was consistent with those for $\mathrm{pH} 4.6 \mathrm{SN}$, with the overall level of proteolysis decreasing in the order: CL > DA1 > DA3 >> DA2.

Storage resulted in a decrease in the concentration of $\alpha_{\mathrm{s} 1}-\mathrm{CN}$ in all cheeses and a concomitant increase in the concentration of $\alpha_{\mathrm{s} 1} \mathrm{CN}$ (f24-199) and its degradation product, $\alpha_{\mathrm{s} 1}-\mathrm{CN}$ (f102-199). The intensity of $\alpha_{\mathrm{s} 1^{-}}$ $\mathrm{CN}$ (f24-199) at $1 \mathrm{~d}$ was highest for the DA1 cheese, which could be due to its higher moisture content and lower calcium-to-casein ratio. It is noteworthy that a reduction in the level of micellar calcium phosphate in milk at $\mathrm{pH} 6.6$ results in greater rennet-induced proteolysis, an effect attributed to the disruption of the casein micelle into subunits, which allows easier access of rennet to the caseins (Fox, 1970). A higher level of residual chymosin activity in the curd, due to the lower $\mathrm{pH}$ at whey drainage, may possibly contribute also to the higher intensity of $\alpha_{\mathrm{s} 1}-\mathrm{CN}$ (f24-199) at $1 \mathrm{~d}$ in DA1 (Creamer et al., 1985). The concentration of $\alpha_{\mathrm{s} 1} \mathrm{CN}$ (f24-199) at 12 to $46 \mathrm{~d}$ was highest in the CL and DA1 cheeses, and at $70 \mathrm{~d}$ was similar in the CL, DA1, and DA3 cheeses. Compared with the other cheeses, there was very little degradation of $\alpha_{\mathrm{s} 1}-\mathrm{CN}$ in the DA2 cheese over the 70-d storage period. The low level of degradation in the DA2 cheese compared with the CL and DA3 cheeses, despite the similar make procedures, gross composition (apart from level of fat), and Ca content, may be attributed to its relatively high $\mathrm{pH}$, which induces a high ratio of colloidal-to-soluble $\mathrm{Ca}$ (Guinee et al., 2000b) and a low degree of proteolysis by rennet (Fox, 1970), a higher degree of casein aggregation, and a lower degree of casein hydration (Sood et al., 1979; Creamer, 1985). It is noteworthy that in the presence of $5 \%$, wt/vol, salt-in-moisture, the degradation of $\alpha_{\mathrm{s} 1}$ $\mathrm{CN}(2 \%, \mathrm{wt} / \mathrm{vol})$ by chymosin decreased as the $\mathrm{pH}$ was increased from 5.2 to 5.8 (Mulvihill and Fox, 1980); it is probable that a similar effect occurred at the low salt-in-moisture concentrations $(\sim 3.0$ to $3.5 \% \mathrm{w} / \mathrm{w})$ in the cheeses in the current study.

$\beta$-Casein was degraded in all cheeses during storage, to an extent depending on $\mathrm{Ca}$ level and $\mathrm{pH}$. At most analysis times, the overall level of proteolysis decreased in the order: DA1 > DA2 $>>$ CL $>$ DA3. Degradation of $\beta$-CN in the DA1 cheese coincided with the formation of $\gamma$-CNs, the concentration of which increased during storage, suggesting that $\beta$-CN was degraded primarily by the indigenous milk plasmin, which has a high specificity for $\beta$-CN. The high level of $\beta$-CN degradation in the DA1 and DA2 cheeses may be attributed to their relatively high $\mathrm{pH}$, which would favor the activity of plasmin, which is optimally active at $\mathrm{pH} \sim 7.5$ (McSweeney and Sousa, 2000). The high level of $\beta$-CN breakdown observed in DA2 also concurs with the observations of Creamer (1976), who noted that the level of $\beta$-CN degradation in Gouda cheese, which has a higher moisture content and $\mathrm{pH}$ than Cheddar, was substantially higher than that in Cheddar.

There was also an increase in the concentration of $\beta$-CN (f1-192), which is formed by chymosin during storage, especially in DA1, due perhaps to the low drain $\mathrm{pH}$ (5.6), which would result in a high level of chymosin in the curd (Creamer et al., 1985). 

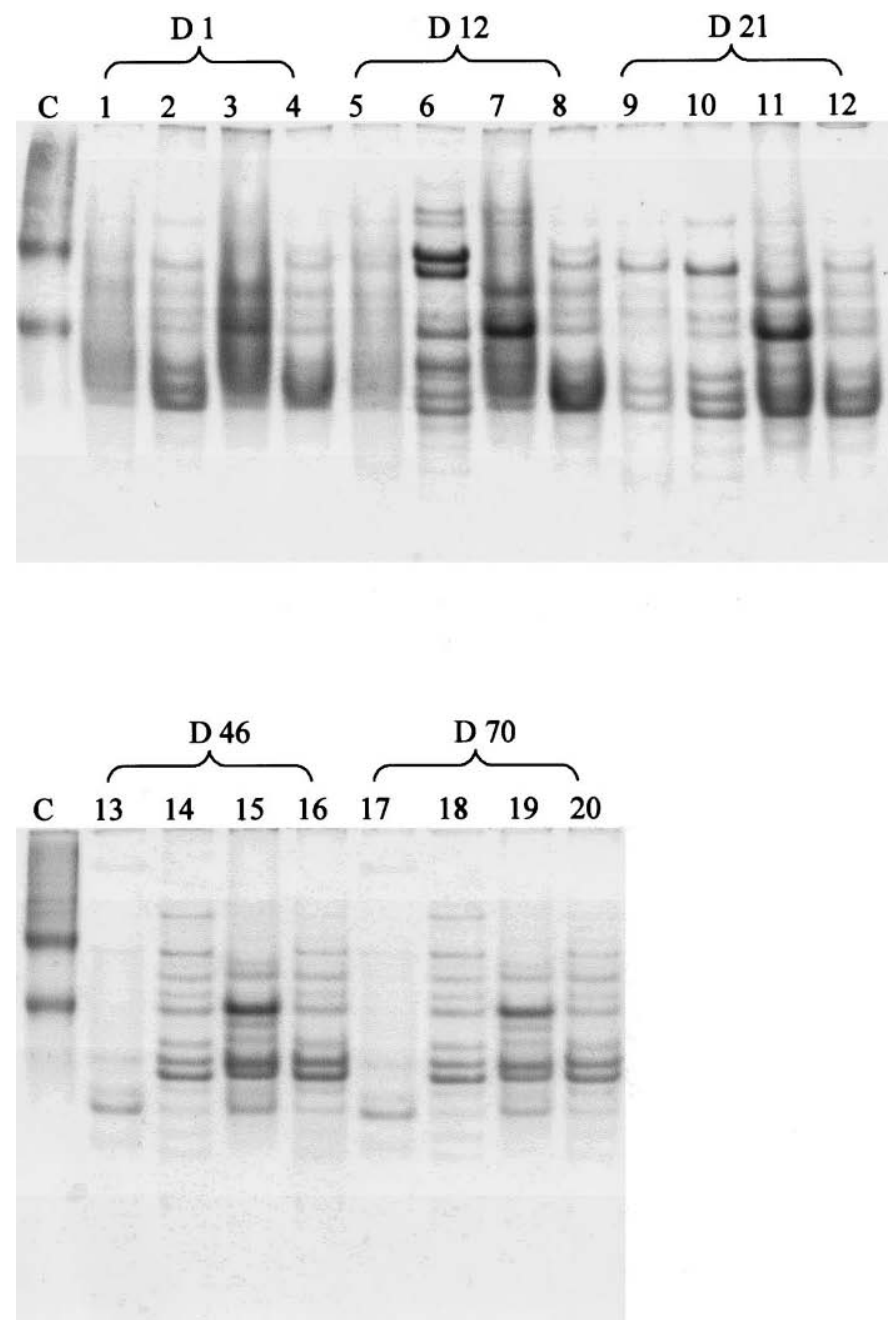

Figure 3. Urea-PAGE of sodium caseinate (C) and the $\mathrm{pH} 4.6$ soluble fraction of Mozzarella cheese made using conventional starter culture acidification ( $\mathrm{pH} 5.42$; Ca $27.7 \mathrm{mg} / \mathrm{g}$ protein; control; lanes, $1,5,9,13$, and 17) or direct acidification to give cheeses with $\mathrm{pH}$ and Ca levels (mg/g protein) of 5.96 and 21.8 (DA1; lanes 2, 6, 10, 14, and 18 ); 5.93 and 29.6 (DA2; lanes, 3, 7, 11, 15, and 19), or 5.58 and 28.7 (DA3; 4, 8, 12, 16, and 20) after ripening for 1, 12, 21, 46, and $70 \mathrm{~d}$ at $4^{\circ} \mathrm{C}$. Details of make procedures and composition are given in the text.

pH4.6-soluble cheese fractions (pH4.6SF). The urea-PAGE electrophoretograms of the $\mathrm{pH} 4.6 \mathrm{SF}$ showed notable differences in the banding pattern between the CL and the DA cheeses (Figure 3). The pH4.6SF of the DA cheeses had a number of bands of high intensity, which were scarcely evident in the $\mathrm{pH} 4.6 \mathrm{SF}$ of CL, especially after storage for $\geq 46 \mathrm{~d}$. These bands may correspond to large peptides which were degraded in CL to small peptides and amino acids by the action of starter cell proteinases and peptidases and which were, therefore, undetected by urea-PAGE. This trend is consistent with the significantly higher level of PTAN in the CL cheese (Figure 1a).
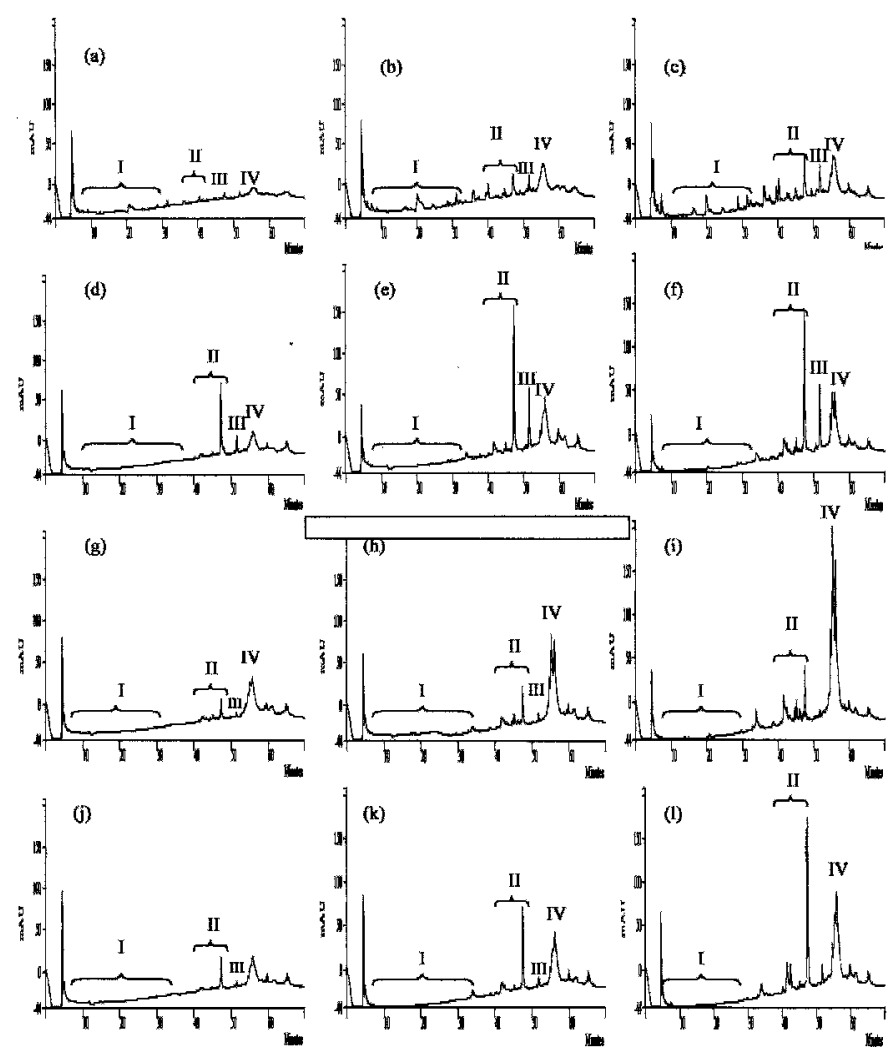

Figure 4. Reversed-phase $\left(\mathrm{C}_{8}\right)$ HPLC profiles of the $\mathrm{pH}$ 4.6-soluble fraction of Mozzarella cheese made using conventional starter culture acidification ( $\mathrm{pH} 5.42 ; \mathrm{Ca} 27.7 \mathrm{mg} / \mathrm{g}$ protein; control, a, b, c) or direct acidification to give cheeses with $\mathrm{pH}$ and Ca levels ( $\mathrm{mg} / \mathrm{g}$ protein) of 5.96 and 21.8 (DA1; d, e, f); 5.93 and 29.6 (DA2; g, h, i), or 5.58 and 28.7 (DA3; j, k, l) after ripening for $1(\mathrm{a}, \mathrm{d}, \mathrm{g}, \mathrm{j}), 21(\mathrm{~b}, \mathrm{e}, \mathrm{h}, \mathrm{k})$, or 70 $\mathrm{d}$ [c, f, i, l (days)] at $4^{\circ} \mathrm{C}$. Details of make procedures and composition are given in the text.

\section{RP-HPLC}

pH 4.6-soluble fractions. RP-HPLC profiles of the lyophilized pH4.6SF of the cheeses at 1,21 , and $70 \mathrm{~d}$ are shown in Figure 4; for convenience, the chromatograms were divided into zones I, II, III, and IV, each of which contained one or more peaks. Similar to previous findings for Cheddar cheeses (Altemueller and Rosenberg, 1996; Lane and Fox, 1997), the chromatograms for all cheeses showed a large number of peaks, indicating a heterogeneous mixture of proteolysis products. In general, the number of peaks remained relatively constant for all cheeses during storage, but there were age-related changes in the area and distribution of different peaks, indicating a transition in the hydrophobicity of peptides. This trend is consistent with the increase in $\mathrm{pH} 4.6 \mathrm{SN}$ in all cheeses and suggests the progressive breakdown of casein by residual coagulant, plasmin, and microbial proteinase, and the resultant formation of peptides of different molecular mass and free amino 
acids. The total peak area, and in particular that of the late eluting peaks, increased during storage.

At all stages of storage, the RP-HPLC profile for the $\mathrm{pH} 4.6 \mathrm{SF}$ of CL differed markedly from those of the DA cheeses. The $\mathrm{pH} 4.6 \mathrm{SF}$ of CL cheese had a greater number and wider distribution of peaks, including the early-eluting peaks (retention time $<30 \mathrm{~min}$ ), denoted collectively as zone I, and which probably correspond to small peptides and free amino acids (Lemieux and Simard, 1992; Altemueller and Rosenberg, 1996). In agreement with the trend noted for PTAN, which is comprised mainly of amino acids and small peptides with a molecular mass $<1.5 \mathrm{kDa}$ (Jarrett et al., 1982), the total area of peaks in zone I increased during storage in the CL cheese but scarcely changed in the DA cheeses. In contrast, the total area of late-eluting peaks (zones II, III, and IV) was generally greater in the DA than in the CL cheese at all analysis times, especially at 46 and $70 \mathrm{~d}$. Therefore, the results suggest a higher concentration of more hydrophobic peptides in the $\mathrm{pH} 4.6 \mathrm{SF}$ of DA cheeses compared to the CL cheese. Peptides rich in hydrophobic amino acid residues have higher retention times on RP-HPLC columns than more hydrophilic peptides (Cliffe and Law, 1990). The larger area of late-eluting peaks in the DA cheeses may reflect the accumulation of rennet-produced peptides, which are not degraded further to peptides of lower hydrophobicity and molecular mass, due to the absence of starter culture peptidases (Lowrie and Lawrence, 1972; Lemieux and Simard, 1992).

Comparison of the pH4.6SF of the different DA cheeses indicated that the areas of peaks in zones II and III were generally lower for the DA2 cheese than for the DA1 and DA3 cheeses. In contrast, the areas of peaks in zone IV were larger for the DA2 cheese than either the DA1 or DA3 cheeses. The differences in the RP-HPLC profiles between the DA2 and other DA cheeses probably reflect the effects of moisture content, $\mathrm{pH}$, and Ca level on proteolysis; the DA2 cheeses had lower moisture and a higher Ca content than the DA1 cheese and had a higher $\mathrm{pH}$ than the DA3 cheese. These differences in composition between the DA2 and the other DA cheeses would be conducive to a lower activity by residual rennet in the former (Fox, 1970; Tam and Whitaker, 1972; Mulvihill and Fox, 1980).

Ethanol soluble fraction. The lyophilized 70\% ethanol-soluble fractions (ESF) were analyzed by RPHPLC. The chromatograms of the ESFs from 1-, 21and 70-d-old cheeses indicated a heterogeneous mixture of peptides (Figure 5). Similar to the trend noted for the RP-HPLC profiles of the pH4.6SF, the total area and number of early-eluting peaks in zone I was higher for the CL cheese than for the DA cheeses, while the total area of the peaks in zones II, III, and IV was markedly higher for the DA cheeses. The relatively large areas of early-eluting peaks indicate a higher proportion of free amino acids in the ESF of the CL cheese, a trend which correlates with its higher concentration of PTAN. The latter trend was expected since the percentage of total $\mathrm{N}$ soluble in $70 \%$ ethanol or 5\% PTA tends to be very similar for different cheeses, including Cheddar of different ages (Kuchroo and Fox, 1982) and Romano-type cheese (Fox and Guinee, 1987). The absence of the early-eluting peaks in the RP-HPLC chromatograms of the ESF of the DA cheeses also agrees with the trend noted for PTAN, the concentration of which remained essentially unchanged at a very low level in DA cheeses during maturation.

\section{CONCLUSIONS}

Low-moisture Mozzarella cheeses (LMMC), differing in $\mathrm{Ca}$ content and $\mathrm{pH}$, were made using a starter culture (CL) or direct acidification with lactic acid (DA1) or lactic acid and GDL (DA2, DA3). The $\mathrm{pH}$ and Ca level significantly affected the moisture content and the type and extent of proteolysis in Mozzarella cheese during the $70-\mathrm{d}$ storage period at $4^{\circ} \mathrm{C}$. For cheeses with a similar pH (i.e., DA1 and DA2), reducing the calcium-tocasein ratio from $\sim 29$ to $22 \mathrm{mg} / \mathrm{g}$ of protein resulted in marked increases in moisture content and in primary and secondary proteolysis, as evidenced by the higher levels of pH4.6SN, PTAN, and degradation of $\alpha_{\mathrm{s} 1^{-}}$and $\beta$-CN. This trend concurs with the observations of Fox (1970), who found that reducing the calcium-to-casein ratio in milk resulted in a higher degree of rennetinduced proteolysis of casein, an effect attributed to the lower degree of casein aggregation (or higher degree of casein hydration). Increasing the $\mathrm{pH}$ from $\sim 5.5$ (as in DA3) to 5.9 (as in DA2), while maintaining the calciumto-casein ratio relatively constant at $\sim 29 \mathrm{mg} / \mathrm{g}$ resulted in a decrease in primary proteolysis but had no effect on secondary proteolysis. However, the extent of $\beta$-casein degradation increased upon raising the $\mathrm{pH}$, probably due to plasmin activity.

Comparison of Mozzarella cheeses with a similar composition but made using a starter culture or direct acidification (i.e., CL and DA3) showed that the CL cheese had higher levels of pH4.6SN and greater degradation of $\alpha_{\mathrm{s} 1}-\mathrm{CN}$ (especially at storage for $\geq 46 \mathrm{~d}$ ). The level of secondary proteolysis in the CL cheese, as monitored by PTAN and RP-HPLC of the 70\% ethanol-soluble fraction, was significantly higher than that in the DA cheeses, suggesting that the starter culture is the main agent responsible for the formation of small peptides and amino acids in low-moisture Mozzarella cheese. 

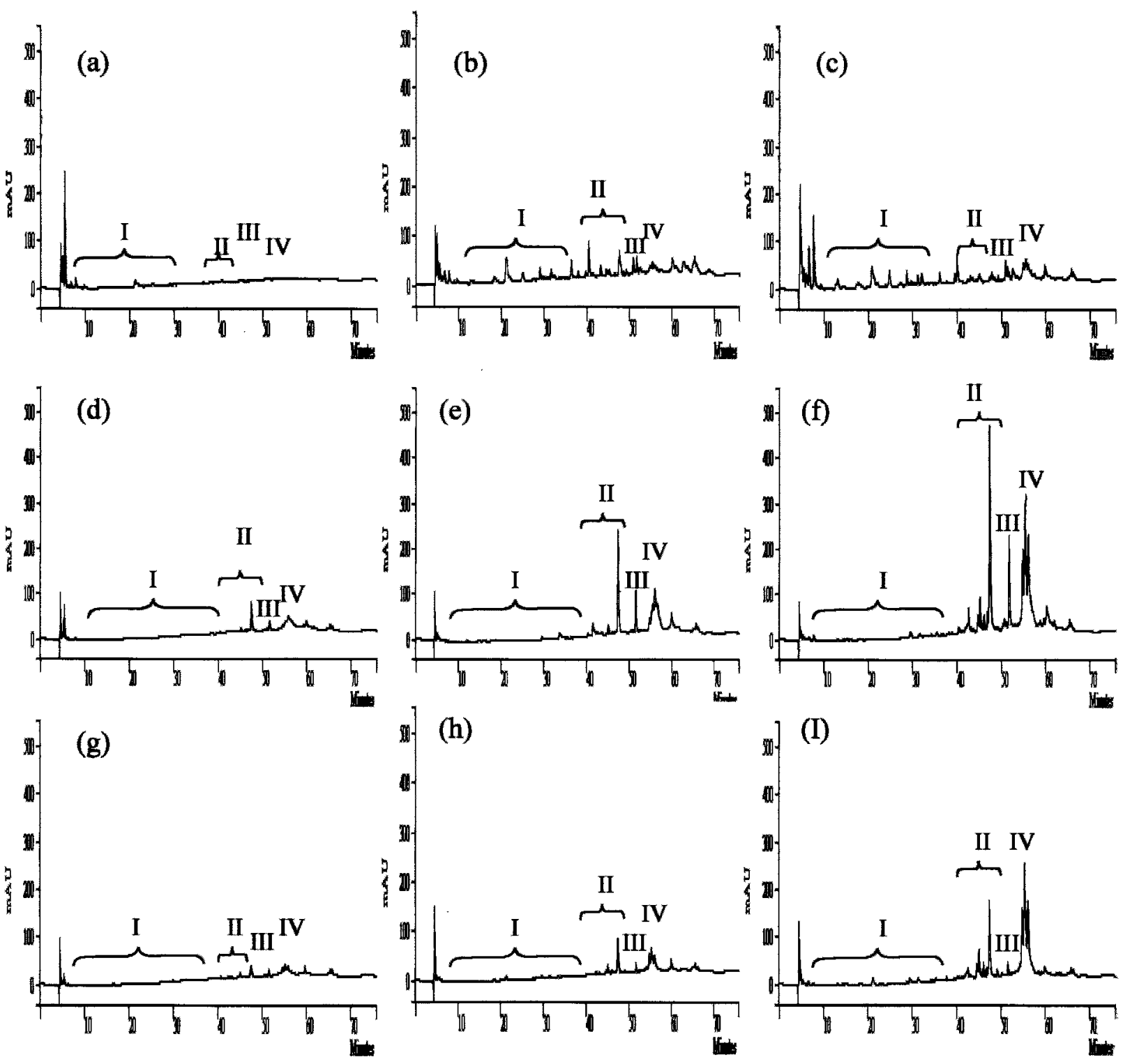

(h)

(I)
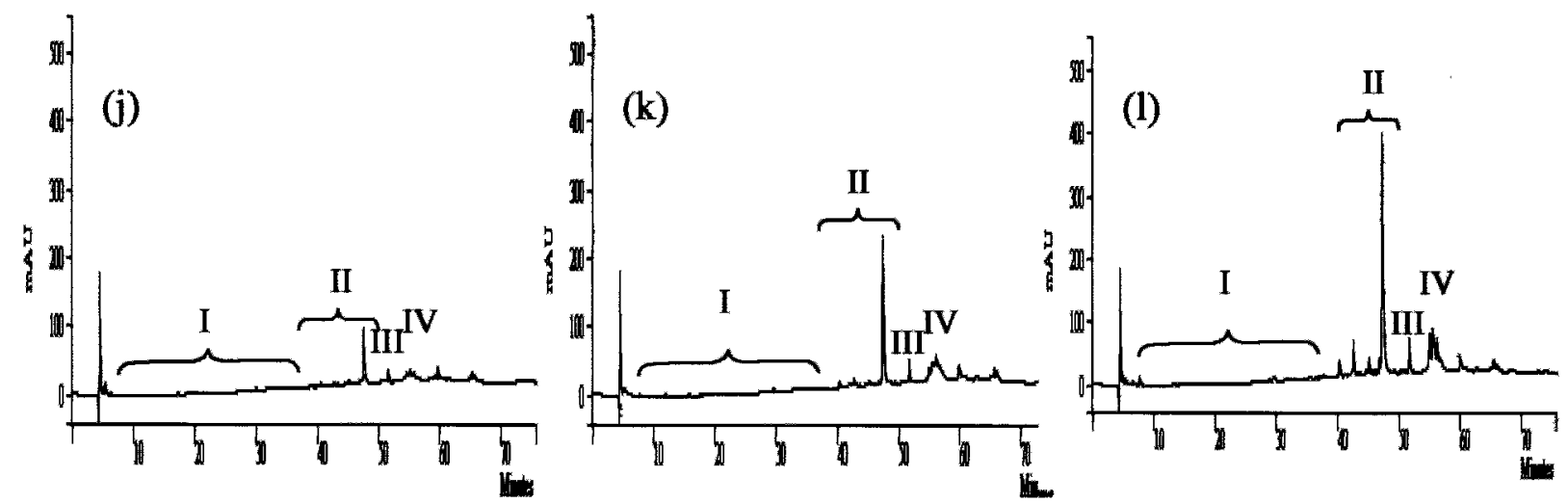

Figure 5. Reversed-phase $\left(\mathrm{C}_{8}\right)$ HPLC profiles of the ethanol-soluble fraction of Mozzarella cheese made using conventional starter culture acidification ( $\mathrm{pH} 5.42$; Ca $27.7 \mathrm{mg} / \mathrm{g}$ of protein; control; a, b, c), or direct acidification to give cheeses with pH and Ca levels (mg/g of protein) of 5.96 and 21.8 (DA1; d, e, f); 5.93 and 29.6 (DA2; g, h, i), and 5.58 and 28.7 (DA3; j, k, l) after ripening for 1 (a, d, g, j), 21 (b, e, h, k), or $70 \mathrm{~d}$ [c, f, i, l (days)] at $4^{\circ} \mathrm{C}$. Details of make procedures and composition are given in the text. 


\section{ACKNOWLEDGEMENTS}

This research was funded in part by the European Union Structural Funds (European Regional Development Fund). The authors kindly acknowledge the technical assistance of E. O. Mulholland and M. O. Corcoran.

\section{REFERENCES}

Altemueller, A. G., and M. Rosenberg. 1996. Monitoring proteolysis during ripening of full-fat and low-fat Cheddar cheeses by reversephase HPLC. J. Food Sci. 61:295-298.

Cliffe, A. J., and B. A. Law. 1990. Peptide composition of enzymetreated Cheddar cheese slurries, determined by reverse phase high performance liquid chromatography. Food Chem. 36:73-80.

Creamer, L. K. 1971. Beta-casein hydrolysis in Cheddar cheese ripening. N.Z. J. Dairy Sci. Technol. 6:91.

Creamer, L. K. 1976. Casein proteolysis in Mozzarella-type cheese. N.Z. J. Dairy Sci. Technol. 11:130-131.

Creamer, L. K. 1985. Water absorption by renneted casein micelles. Milchwissenschaft 40:589-591.

Creamer, L. K., and N. F. Olson. 1982. Rheological evaluation of maturing Cheddar cheese. J. Food Sci. 47:631-646.

Creamer, L. K., R. C. Lawrence, and J. Gilles. 1985. Effect of acidification of cheese milk on the resultant Cheddar cheese. N.Z. J. Dairy Sci. Technol. 20:185-203.

Feeney, E. P., P. F. Fox, and T. P. Guinee. 2001. Effect of ripening temperature on the quality of low moisture Mozzarella cheese: I. Composition and proteolysis. Lait. 81:463-474.

Fenelon, M. A., P. O'Connor, and T. P. Guinee. 2000. The effect of fat content on the microbiology and proteolysis in Cheddar cheese during ripening. J. Dairy Sci. 83:2173-2183.

Fox, P. F. 1970. Influence of aggregation on the susceptibility of casein to proteolysis. J. Dairy Res. 37:173-180.

Fox, P. F., and T. P. Guinee. 1987. Italian cheeses. Pages 221-255 in Cheese: Chemistry, Physics and Microbiology. Vol 2. Major Cheese Groups. P. F. Fox, ed. Elsevier Applied Science, London.

Fox, P. F., T. P. O'Connor, P. L. H. McSweeney, T. P. Guinee, and N. M. O’Brien. 1996. Cheese: physical, biochemical, and nutritional aspects. Adv. Food Nutrit. Res. 39:163-328.

Guinee, T. P., E. O. Mulholland, C. Mullins, M. O. Corcoran, J. F. Connolly, T. Beresford, R. Mehra, B. O'Brien, J. J. Murphy, and G. Stakelum. 1998. Effect of altering daily herbage allowance to cows in mid lactation on the composition, ripening and functionality of low-moisture, part-skim Mozzarella cheese. J. Dairy Res. 65: 23-30.

Guinee, T. P., M. A. E. Auty, and M. A. Fenelon. 2000a. The effect of fat on the rheology, microstructure, and heat-induced functional characteristics of Cheddar cheese. Int. Dairy J. (accepted).

Guinee, T. P., D. Harrington, M. O. Corcoran, E. O. Mulholland, and C. Mullins. 2000b. The composition and functional properties of commercial Mozzarella, Cheddar, and analogue pizza cheese. Int. J. Dairy Technol. 53:51-56.

Guinee, T. P., E. O. Mulholland, C. Mullins, and M. O. Corcoran. 2000c. Effect of salting method on the composition, yield, and functionality of low-moisture Mozzarella cheese. Milchwissenschaft. 55:135-138.

Guinee, T. P., E. P. Feeney, and P. F. Fox. 2002. Effect of pH and calcium level on the textural and functional properties of lowmoisture Mozzarella cheese. J. Dairy Sci. (accepted).

Jarrett, W. D., J. W. Aston, and J. R. Dulley. 1982. A simple method for estimating free amino acids in Cheddar cheese. Aust. J. Dairy Technol. 37:55-58.

Kimura, T., Y. Sagara, M. Fukushima, and S. Taneya. 1992. Effect of $\mathrm{pH}$ on the submicroscopic structure of string cheese. Milchwissenschaft 47:547-552.
Kindstedt, P. S., J. J. Yun, D. M. Barbano and K. L. Larose. 1995. Mozzarella cheese: impact of coagulant concentration on chemical composition, proteolysis, and functional properties. J. Dairy Sci. 78:2591-2597.

Kindstedt, P. S., and M. R. Guo. 1997. Chemically-acidified pizza cheese production and functionality. Pages 24-30 in Proc. 5th Cheese Symposium. T. M. Cogan and P. F. Fox, ed., Teagasc, Dublin.

Kuchroo, C. N., and P. F. Fox. 1982. Soluble nitrogen in cheese: comparison of extraction procedures. Milchwissenschaft 37:331-335.

Lane, C. N., and P. F. Fox. 1997. Role of starter enzymes during ripening of Cheddar cheese made from pasteurized milk under controlled microbiological conditions. Int. Dairy J. 7:55-63.

Lemieux, L., and R. E. Simard. 1992. Bitter flavour in dairy products. II. A review of bitter peptides from caseins: their formation, isolation, and identification structure masking and inhibition. Lait. 72:335-382.

Lowrie, R. J., and R. C. Lawrence. 1972. Cheddar cheese flavour. IV. A new hypothesis to account for the development of bitterness. N.Z. J. Dairy Sci. Technol. 7:51-53.

McSweeney, P. L. H., and M. J. Sousa, 2000. Biochemical pathways for the production of flavour compounds in cheeses during ripening: a review. Lait 80:293-324.

Mulvihill, D. M., and P. F. Fox. 1977. Proteolysis of $\alpha_{\mathrm{s} 1}$-casein by chymosin: influence of $\mathrm{pH}$ and urea. J. Dairy Res. 44:533-540.

Mulvihill D. M., and P. F. Fox 1980. Proteolysis of $\alpha_{\mathrm{s} 1}$-casein by chymosin in dilute $\mathrm{NaCl}$ solutions and in Cheddar cheese. Irish. J. Food. Sci. Technol. 4:13-23.

O'Keeffe, R. B., P. F. Fox, and C. Daly. 1975. Proteolysis in Cheddar cheese: influence of the rate of acid production during manufacture. J. Dairy Res. 42:111-122.

O'Keeffe, R. B., P. F. Fox, and C. Daly. 1978. Proteolysis in Cheddar cheese: role of coagulant and starter bacteria. J. Dairy Res. $45: 465-477$

Renda, A., D. M. Barbano, J. J. Yun, P. S. Kindstedt, and S. J. Mulvaney. 1997. Influence of screw speeds of the mixer at low temperature on characteristics of Mozzarella cheese. J. Dairy Sci. 80:1901-1907.

SAS User's Guide: Statistics, Version 6.12 Edition. 1995. SAS Inst., Inc., Cary, NC.

Sood V. K., D. K. Gaind, and R. K. Dewan. 1979. Correlation between micelle solvation and calcium content. N.Z. J. Dairy Sci. Technol. 14:32-34.

Tam, J. T., and J. R. Whitaker. 1972. Rates and extents of hydrolysis of several caseins by pepsin, rennin, Endothia parasitica and Mucor pusillus proteinase. J. Dairy Sci. 55:1523-1531.

Thunell, R. K., J. W. Duersch, and C. A. Ernstrom. 1979. Thermal inactivation of residual milk clotting enzymes in whey. J. Dairy Sci. 62:373-377.

Visser, F. M. W. 1977. Contribution of enzymes from rennet, starter bacteria, and milk to proteolysis and flavour development in Gouda cheese. 3. Protein breakdown: analysis of the soluble $\mathrm{N}$ and amino acid nitrogen fractions. Neth. Milk Dairy J. 31:210-239.

Visser F. M., and E. A. de Groot-Mostert. 1977. Contribution of enzymes from rennet, starter bacteria, and milk to proteolysis and flavour development in Gouda cheese. IV. Protein breakdown: a gel electrophoretical study. Neth. Milk. Dairy J. 31:247-264.

Walsh, C. D., T. P. Guinee, D. Harrington, R. Mehra, J. J. Murphy, and R. J. Fitzgerald. 1998. Cheesemaking, compositional, and functional characteristics of low-moisture Mozzarella, part-skim Mozzarella cheese from bovine milks containing $\kappa$-casein AA, AB, or BB genetic variants. J. Dairy Res. 65:307-315.

Yun, J. J., D. M. Barbano, and P. S. Kindstedt. 1993. Mozzarella cheese: impact of coagulant type on chemical composition and proteolysis. J. Dairy Sci. 76: 3648-3656.

Yun, J. J., D. M. Barbano, and P. S. Kindstedt. 1993. Mozzarella cheese: impact of milling $\mathrm{pH}$ on chemical composition and proteolysis. J. Dairy Sci. 76:3629-3638. 